\title{
Giant intracranial calcification associated with new onset focal seizure
}

\author{
Pawel P Jankowski, ${ }^{1}$ Denise M Malicki, ${ }^{2}$ Michael L Levy, ${ }^{1}$ John Ross Crawford ${ }^{3}$
}

${ }^{1}$ Department of Neurosurgery, University of California San Diego, San Diego, California, USA

${ }^{2}$ Department of Pathology, Rady Children's Hospital University of California San Diego, San Diego, California, USA

${ }^{3}$ Department of Neurosciences and Pediatrics, University of California San Diego, San Diego, California, USA

Correspondence to Dr John Ross Crawford, jrcrawford@ucsd.edu
To cite: Jankowski PP, Malicki DM, Levy ML, et al. BMJ Case Rep Published online: [please include Day Month Year] doi:10.1136/ bcr-2013-010514

\section{DESCRIPTION}

We present a case of a 10-year-old boy with a 2-week history of focal seizures involving the right side of his face. His medical history was remarkable for pulmonary tuberculosis at 5 years of age without central nervous system involvement. A CT of the head showed a large $2 \mathrm{~cm}$ subcortical calcification in the left frontal lobe with surrounding oedema (figure 1A-C). MRI revealed characteristics of a heavily calcified mass with associated oedema and cortical thinning (figure 1D-F). Lumbar puncture was normal. EEG demonstrated left frontocentral epileptiform discharges. Owing to the size of the mass and the associated oedema, the patient was taken to surgery where gross total resection demonstrated a giant area of heterotopic ossification (figure 2). The child tolerated the procedure well and was placed postoperatively on levetiracetam and has been seizure-free at 12 months of follow-up.

The differential diagnosis of localised calcified brain nodules includes meningio-angiomatosis, psammomatous meningioma, primary or metastatic tumours, toxoplasmosis/tuberculosis and vascular malformations. Based on the child's medical history it was thought that the lesion could be consistent with a calcified parenchymal granulomata that can be seen in up to $20 \%$ of patients with a history of tuberculosis. ${ }^{1}$ However, the histological evaluation revealed a heterotopic ossification most consistent with a calcified cavernous angioma. Cavernous angiomas that do not haemorrhage may have stippled calcifications in the vessel wall or in the parenchyma of brain. ${ }^{23}$ Our case highlights the differential diagnosis of heavily calcified focal brain lesions as a presenting feature of new onset seizures.
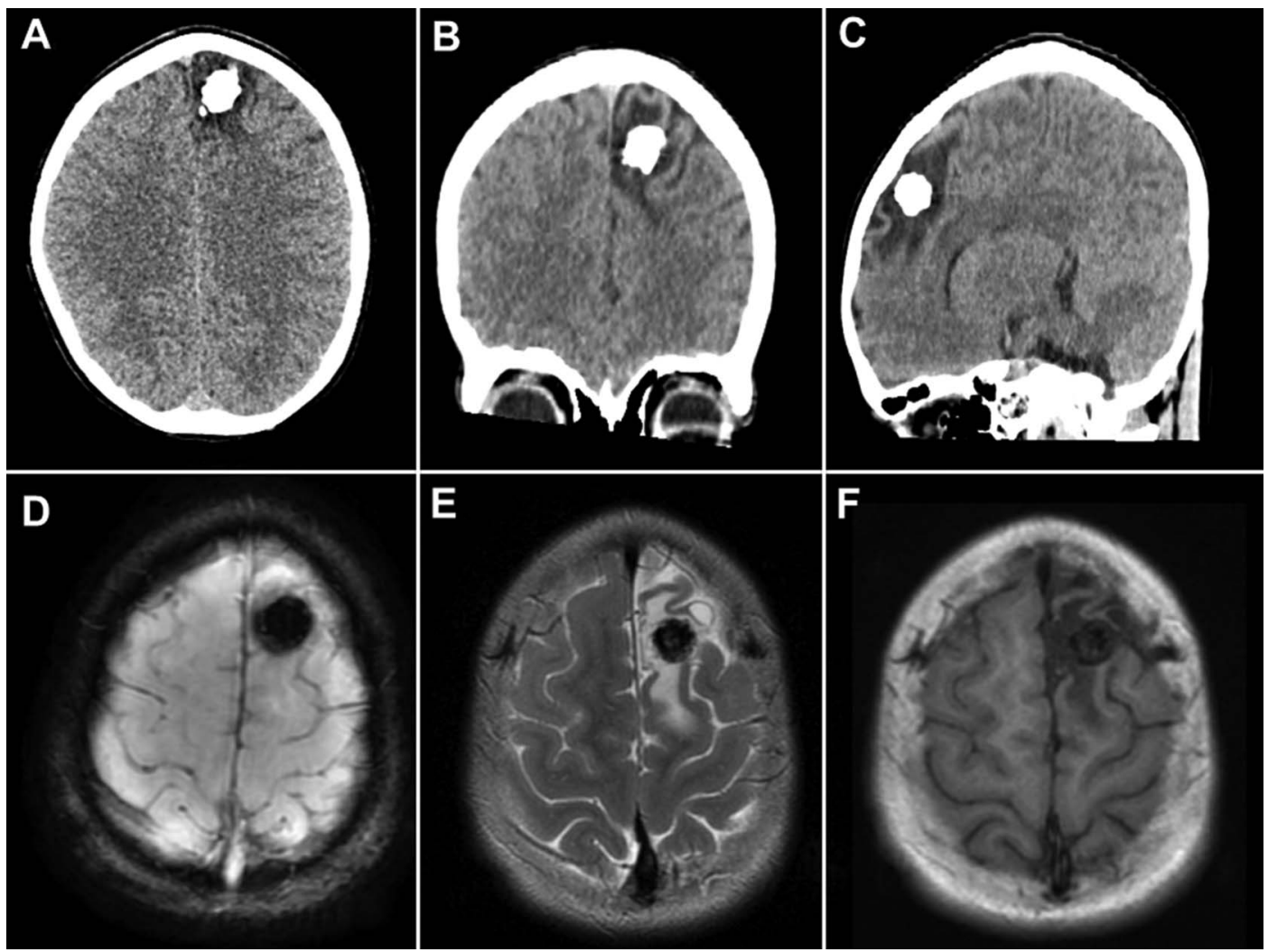

Figure 1 Neuroimaging features of giant intracranial calcification. (A-C) Axial, coronal and sagittal non-contrast head CT shows a large $2 \mathrm{~cm}$ cortical-subcortical hyperdensity in the left frontal lobe with surrounding oedema. (D-F) MRI reveals an area of susceptibility weighted artefact on SWI sequence (D) with similar appearance on T2 (E) and T1-weighted sequence (F) consistent with calcification. 

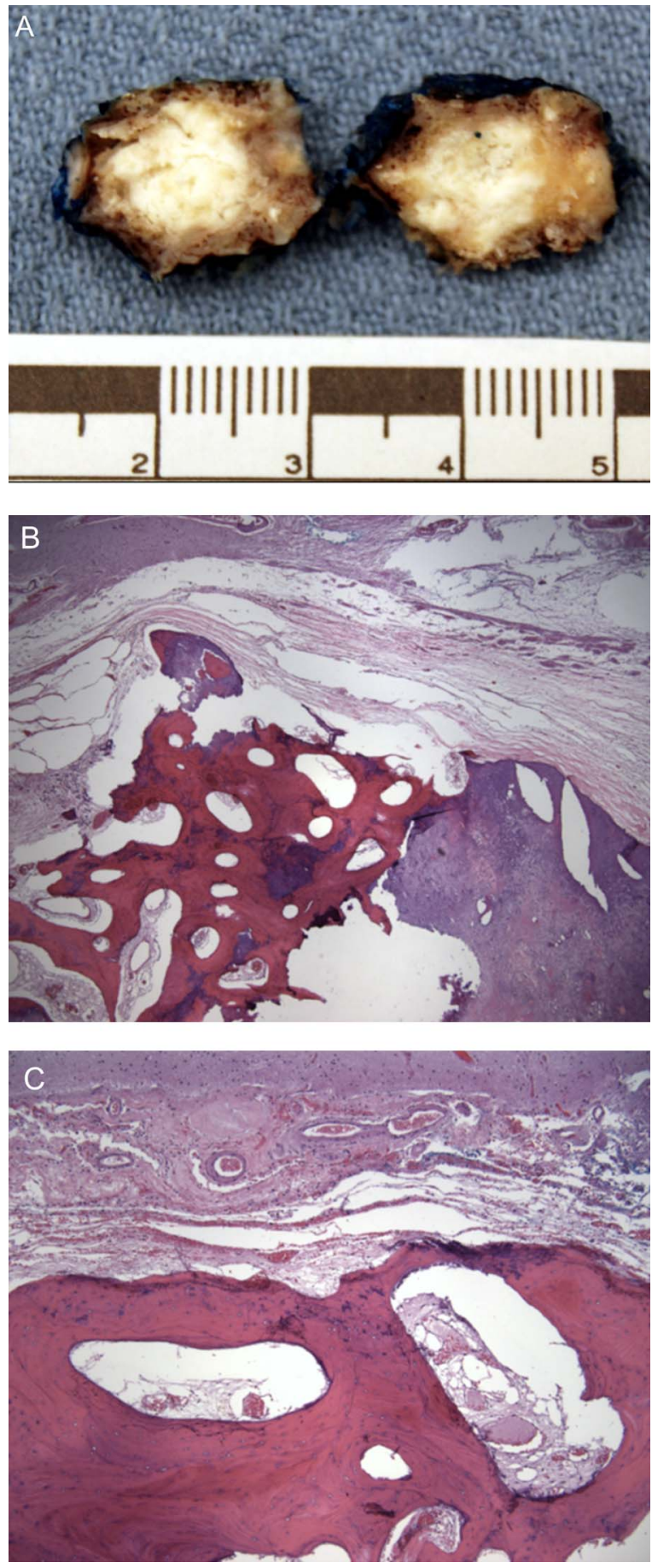

Figure 2 Gross and microscopic features of giant intracranial calcification (A). Gross specimen postoperatively reveals a hard nodule of tan to pink tissue measuring $2.2 \times 1.5 \times 0.8 \mathrm{~cm}$. H\&E section at $\times 40$ (B) and $\times 100$ (C) reveals an area of heterotopic calcification that is associated with areas of prominent vessels most consistent with ossification of a vascular malformation.

\section{Learning points}

- Patients with a new solitary intracranial calcification should be evaluated for infection, neoplasm, vascular malformation and systemic disease in order to help elucidate the aetiology of the mass.

- Complete surgical resection of calcified intraparenchymal lesions associated with partial complex seizures is safe and can be associated with excellent prognosis.

- A non-neurosurgical observation only approach in cases of newly diagnosed focal brain lesions associated with or without seizures may be appropriate depending on the history, examination and neuroradiographic features of the lesion.

Contributors All authors have contributed equally to the design and constructing of the manuscript. All authors have reviewed the manuscript prior to submission and have agreed to its content.

Competing interests None.

Patient consent Obtained.

Provenance and peer review Not commissioned; externally peer reviewed.

\section{REFERENCES}

1 Wasay M, Kheleani BA, Moolani MK, et al. Brain CT and MRI findings in 100 consecutive patients with intracranial tuberculoma. J Neuroimaging 2003;13:240-7.

2 Nakase H, Morimoto T, Tsunoda S, et al. Cortical and subcortical cavernous angioma: a comparison of patients with and without hemorrhage as the initial symptom. Neurol Med Chir (Tokyo) 1992;32:196-200.

3 Shaida AM, McFerran DJ, da Cruz M, et al. Cavernous haemangioma of the internal auditory canal. J Laryngol Otol 2000;114:453-5. 
Copyright 2013 BMJ Publishing Group. All rights reserved. For permission to reuse any of this content visit http://group.bmj.com/group/rights-licensing/permissions.

BMJ Case Report Fellows may re-use this article for personal use and teaching without any further permission.

Become a Fellow of BMJ Case Reports today and you can:

- Submit as many cases as you like

- Enjoy fast sympathetic peer review and rapid publication of accepted articles

- Access all the published articles

- Re-use any of the published material for personal use and teaching without further permission

For information on Institutional Fellowships contact consortiasales@bmjgroup.com

Visit casereports.bmj.com for more articles like this and to become a Fellow 